the same carrier specificity as delayed hypersensitivity (Oppenheim et al., 1967; Senyk et al., 1971).

In-vitro lymphocyte stimulation, which is thought to represent mainly cell-mediated immunity against $\mathrm{HBAg}$, was shown up to 72 weeks after the last signs of hepatitis in nine of our group of 12 patients who had recovered from the disease. Only five showed transient antibodies, and in these five an immune response against HBAg could be shown with in-vitro lymphocyte stimulation after the $\mathrm{HB}$ antibodies had disappeared. Two of the three patients who showed no stimulation were tested within four weeks of the disappearance of HBAg from their serum, but in that interval a cell-mediated immune response may not be detectable with in-vitro lymphocyte stimulation.

The fact that lymphocyte sensitization as well as antibody formation were also found in the group of laboratory technicians shows that a complete immune response can develop after exposures to $\mathrm{HBAg}$ which do not result in an attack of hepatitis. In two cases antibodies were detected without in-vitro lymphocyte stimulation. Perhaps such differences in the immune response may be related to the dose of $\mathrm{HBAg}$, the subtype, the mode of transmission, or to genetic factors.

Most proteins lose their ability to induce antibody formation after heat-denaturation but remain as effective as untreated proteins in inducing delayed hypersensitivity (Gell and Benacerraf, 1959). Purified $\mathrm{HBAg}$ denatured by reduction and alkylation was found to have lost its ability to induce a humoral reaction in guinea-pigs but its ability to induce delayed hypersensitivity was unaffected (Vyas et al., 1972). In contrast, we found that heat-inactivated purified HBAg elicited an antibody response in guinea-pigs. Moreover, it was found to be immunologically identical to untreated HBAg in immunodiffusion using monospecific antisera. Krugman and Giles (1973) found antibodies against $\mathrm{HBAg}$ in some people after immunization with heat-inactivated HBAg-rich serum, while Soulier et al. (1972) found antibodies in all of seven persons immunized with a higher dose. In our studies purified, heat-inactivated $\mathbf{H B A g}$ stimulated sensitized lymphocytes in vitro.

These findings suggest that vaccination with purified, heatinactivated HBAg might induce not only humoral but also cellmediated immunity against serum hepatitis. Further studies are needed to show whether cell-mediated rather than humoral immunity against HBAg offers protection against hepatitis B.

This work was supported by a grant from the Netherlands Kidney Foundation.

\section{References}

Böyum, A. (1968). Scandinavian fournal of Clinical and Laboratory Investigation, 21, 77.

Dudley, F. J., Fox, R. A., and Sherlock, S. (1972 a). Lancet, 1, 723.

Dudley, F. J., Giustino, V., and Sherlock, S. (1972 b). British Medical Fournal, 4, 754.

Gell, P. G. H., and Benacerraf, B. (1959). Immunology, 2, 64.

Houwen, B., Marrink, J., Vos, J., Molenaar, I., and Nieweg, H. O. (1973). Vox Sanguinis, Suppl., 24, 114. Krugman, S., Giles, J. P., and Hammond, J. (1970). Journal of Infectious
Diseases, 122, 432.

Krugman, S., and Giles, J. P. (1973). New England fournal of Medicine, 288, 755 .

Oppenheim, J. J., Wolstencroft, R. A., and Gell, P. G. H. (1967). Immunology,

Roitt, I. M., Graves, M. F., Torrigiani, G., Brostoff, J., and Playfair, J. H. L.' (1969). Lancet, 2, 367.

Senyk, G., Williams, E. B., Nitecki, D. E., and Goodman, J. W. (1971). Journal of Experimental Medicine, 133, 1294.

fournal of Experimental Medicine, 133, 1294.
Soulier, J. P., et al. (1972). American fournal of Diseases of Children, 123, 429.

Soulier, J. P., et al. (1972). American fournal of Diseases of Children, 123,

Vyas, G. N., Rao, K. R., and Ibrahim, A. B. (1972). Science, 178, 1300.

Yeung, Laiwah, A. A. C. (1971). Lancet, 2, 470.

\title{
Changes in Antigenic Nature of Lymphocytes Caused by Common Viruses
}

\author{
ELIZABETH THOMPSON, CYNTHIA M. LEWIS, G. D. PEGRUM
}

\section{Introduction}

Recently we reported unexpected reactivity between the lymphocytes of two identical twins (Pegrum et al., 1972). At the time it was noticed that the twin whose cells caused the reactivity was suffering from a heavy cold. When he recovered no reaction occurred between these siblings' lymphocytes. This observation suggested the possibility that the surface antigens on the stimulating lymphocytes had been altered by the viral infection. Such a change might account for the observation that lymphoblastoid cell lines obtained from patients with glandular fever cause reactivity of the subject's own lymphocytes after recovery (Steel and Hardy, 1970).

To test this hypothesis further lymphocytes were cultured in a nutrient medium with three viruses. After incubation cultures were irradiated and the cells washed. These were then placed in contact with fresh autologous lymphocytes and the reactivity was assessed.

\section{Materials and Methods}

PREPARATION OF VIRUSES

Influenza A2/Singapore/57 virus was grown at $37^{\circ} \mathrm{C}$ in the allantoic fluid of 10-day-old fertile hens' eggs. After three days 
the allantoic fluid was removed and the virus recovered in the supernatant after centrifugation. Herpes simplex type 1 and adenovirus type 2 were grown in human diploid embryonic fibroblasts (M.R.C.5) in Eagle's medium with $10 \%$ fetal calf serum and $10 \%$ tryptose phosphate broth. After three days the cell cultures were repeatedly frozen and thawed to break up the cells and release the virus. The cell fragments were removed by centrifugation and the supernatant was used as the source of virus. The influenza virus was titrated againt $\mathrm{O}$-positive blood cells and the same concentration used in all experiments. The titre of the herpesvirus and adenovirus was unknown but aliquots of the same batch were used throughout.

\section{PREPARATION OF CULTURES}

A 30-ml sample of blood from healthy donors was taken into heparin; the leucocyte-rich plasma was allowed to separate and was then removed. Lymphocytes were separated from the plasma using a column of nylon fibre. The column was prepared by packing a $10-\mathrm{ml}$ syringe with nylon fibre and then washing through with Eagle's M.E.M. Leucocyte-rich plasma was introduced through the top and allowed to soak into the nylon. The column was incubated at $37^{\circ} \mathrm{C}$ for 30 minutes and lymphocytes were obtained by washing with $20 \mathrm{ml}$ of Eagle's medium. This method gives over $95 \%$ of lymphocytes.

A cell count was performed and the volume adjusted to give approximately $2 \times 10^{6}$ cells $/ \mathrm{ml}$ in Eagle's M.E.M. ( + Hepes) and $10 \%$ fetal bovine serum. Aliquots of this cell suspension were incubated for 48 hours at $37^{\circ} \mathrm{C}$ with (a) influenza A2/ Singapore/57, (b) herpes simplex type 1 , and (c) adenovirus type 2. Further aliquots were incubated for the same period with virus which had been inactivated by irradiation $(5,000$ rads). A control sample of lymphocytes alone was set up at the same time. After two days all cultures were expcsed to 5,000 rads to inactivate both virus and lymphocytes. The cells were subsequently washed three times with Eagle's M.E.M. to remove any free virus. Before irradiation an aliquot was removed from each culture and pulsed with ${ }^{3} \mathrm{H}$-thymidine as described below to assess any reactivity at this stage.
A further $30 \mathrm{ml}$ of blood was taken from the same donor and another lymphocyte preparation made as described. Duplicate microcultures were then prepared by placing equal numbers of the irradiated cells with fresh, untreated lymphocytes to give a total volume of $1 \mathrm{ml}$ with $1 \times 10^{6}$ cells. Control cultures of lymphocytes and irradiated cells alone were prepared. Further controls of lymphocytes with the supernatant of washed irradiated cells were also prepared. The cultures were incubated for five days at $37^{\circ} \mathrm{C}$. Sixteen hours before the end of culture $2.5 \mu \mathrm{Ci}{ }^{3} \mathrm{H}$-methylthymidine (with a specific activity of 5.0 $\mathrm{Ci} / \mathrm{mmol}$ ) was added to each tube.

Samples were prepared for scintillation counting by placing duplicate $0 \cdot 1-\mathrm{ml}$ aliquots from each culture on Whatman paper discs (grade $3 \mathrm{~mm}$, size $1.9 \mathrm{~cm}$ ). These discs were dried, treated with $20 \%$ trichloroacetic acid for 10 minutes at $4^{\circ} \mathrm{C}$, and then washed with $3 \%$ perchloric acid. Further washing and drying was effected with methanol and ether. The dried discs were placed in $20 \mathrm{ml}$ scintillation fluid $(4 \mathrm{~g}$ PPO and $100 \mathrm{mg}$ dimethyl POPOP/1. analar toluene) and the radioactivity was assessed using a Nuclear Enterprise $\beta$ counter.

\section{Results}

The cells treated with viable virus after 48 hours and before irradiation showed no increase in DNA synthesis. The irradiated virus-treated lymphocytes placed with fresh, untreated lymphocytes from the same donor for five days caused an increase in DNA synthesis when compared with identical lymphocytes cultured with irradiated lymphocytes without viral pretreatment (see table). The results were not uniform in the six donors tested, and in donor 5 a negative effect was produced by the cells pretreated with influenza virus. But in all other instances an effect was produced, and the degree of response was consistent in each individual. The range and mean results of three separate cultures using donor 1 are shown in the chart.

Though the dose of irradiation used to inactivate the lymphocytes probably does not kill the viruses, DNA synthesis of newly forming virus particles cannot be responsible for the uptake of thymidine. Viral DNA synthesis would be expected to occur

Uptake of ${ }^{3} \mathrm{H}$-Thymidine by Lymphocytes in Mixed Culture with Autologous Irradiated Pretreated Lymphocytes. Results expressed as c.p.m./105 Cells

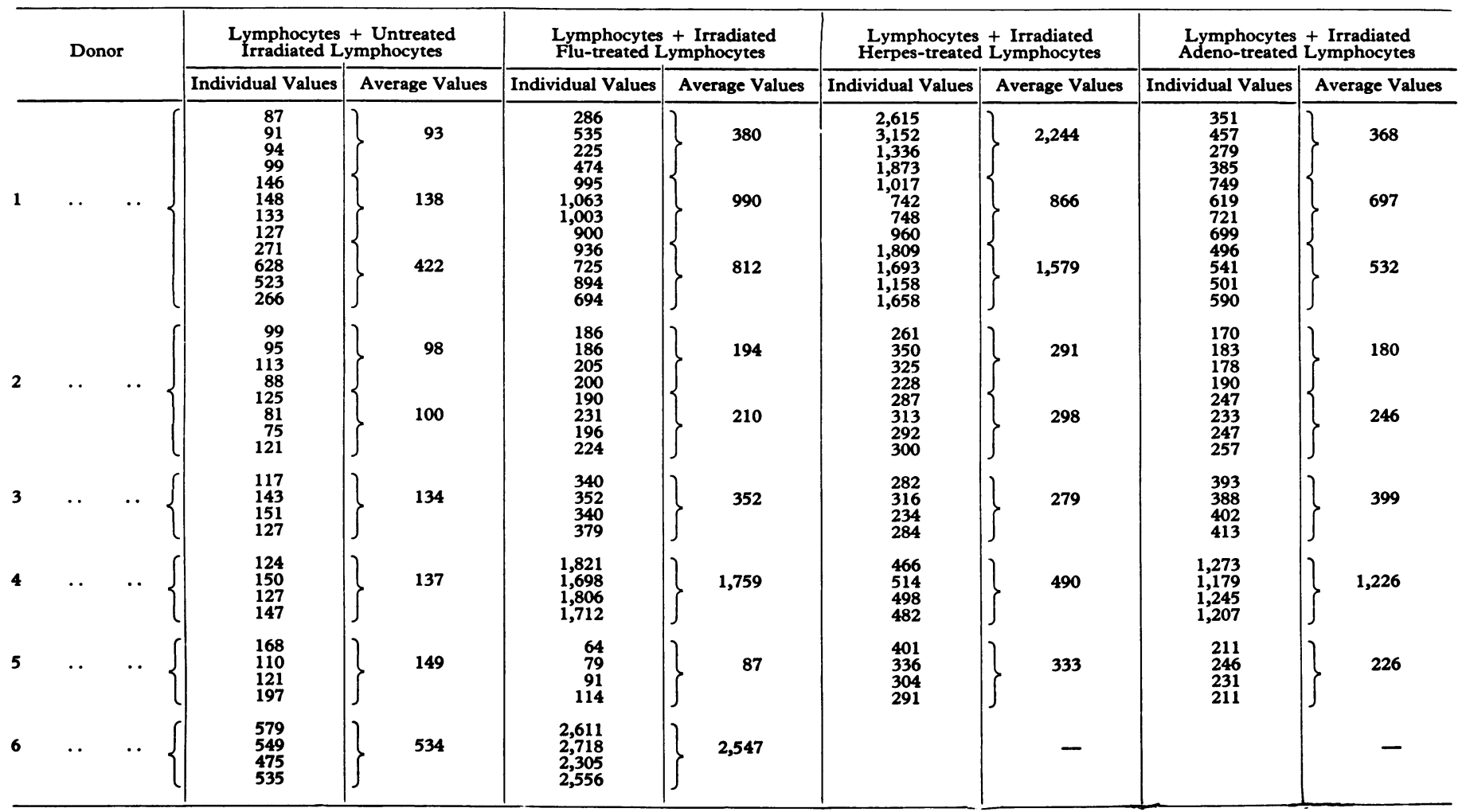




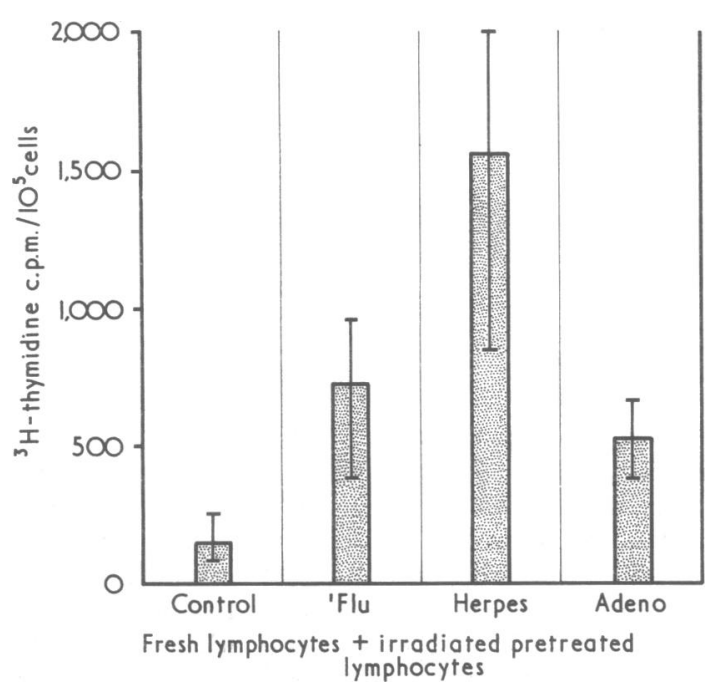

Range and mean results of three separate cultures using one donor.

during the first day of culture and no DNA synthesis was evident at any time in lymphocytes treated with virus and subsequently inactivated. The uptake of thymidine cannot be attributed to viral activity in cultures treated with influenza, since this virus contains only RNA.

In two cultures in which inactivated influenza A2 virus was used to pretreat the stimulating lymphocytes the degree of thymidine incorporation was of the same order as when viable virus was used. This suggests that viral multiplication is not essential for the lymphocyte reactivity that we have observed, and it implies that the virus acts as an antigen. The supernatant from virus-treated lymphocytes which had been irradiated, however, caused no activation of fresh lymphocytes, though such supernatants might be expected to contain inactivated virus. The stimulatory capacity of the virus-treated lymphocyte cultures is therefore a function of the lymphocytes. We do not know whether this results from virus becoming attached to the cells or from membrane changes induced by virus.

Cells that had been only irradiated gave no significant counts when exposed to ${ }^{3} \mathrm{H}$-thymidine.

\section{Discussion}

It has been shown that experimentally-induced viral tumours have surface antigens which will cross-react with one another (Klein, 1966). Similar changes are thought to occur in certain human tumours. For example, serum from a patient with Burkitt's lymphoma in remission has been shown to react specifically against the cells from others with this condition (Klein et al.,
1967). This suggests that there is a specific antigenic change in cells affected by the Epstein-Barr virus. Cultured glandular fever cells react with fresh autologous lymphocytes once the patient has recovered (Steel and Hardy, 1970), and since both these conditions are associated with viruses which have rather similar properties (Henle et al., 1968) it appears likely that there is alteration of cell surface antigens due to the presence of this organism.

The findings presented here indicate that common viral infections can alter the surface characteristics of lymphocytes so that there is reactivity between affected and unaffected cells from the same individual. We do not know if this response is due to the virus becoming attached to the lymphocytes, or to an internal change with the formation of neoantigens, or to the presence of virus in the structure of the cell membrane.

Inactivated virus causes the same reactivity; thus whatever the underlying mechanism the change is determined by the lymphocytes themselves, as the subsequent stimulation of the autologous cells occurs without proliferation of the virus. Anomalous results in mixed cell cultures might well be caused by virally induced changes though such involvement was thought unlikely to explain the enhanced MLC reactivity caused by certain cell lines, some of which are known to be contaminated with virus (Hardy et al., 1969; Hardy et al., 1970).

Our observations may well be relevant to the progress of certain renal allografts. Hyperacute rejection has occurred after the transplantation of a kidney from an HL-A identical sibling suffering from a viral infection $(\mathrm{H}$. Festenstein, personal communication), while viral infection in the host has been associated with episodes of accelerated rejection (Lopez et al., 1973). It is not only viral infections that influence the course of renal allografts, for in dogs accelerated rejection occurs after pretreatment of the host with group A streptococci (Rapaport et al., 1971). The influence of infection on the immunological status of a potential donor or recipient may well relate to the subsequent fate of any graft. Such responses might explain instances of rapid rejection which sometimes unexpectedly occur. It seems sensible to delay transplantation between identical siblings if the donor has even a mild viral infection.

We should like to thank the Lawson Tait Medical and Scientific Research Trust and the West London Medical Trust for supporting this work.

\section{References}

Hardy, D. A., Ling, N. R., and Knight, Stella C. (1969). Nature, 223, 511. Hardy, D. A., Knight, Stella, C., and Ling, N. R. (1970). Immunology, 19,

Henle, G., Henle, W., and Diehl, V. (1968). Proceedings of the National Academy of Sciences, 59, 94.

Klein, G. (1966). Annual Review of Microbiology, 20, 223.

Klein, G., Klein, E., and Clifford, P. (1967). Cancer Research, 27, 2510.

Lopez, C., et al. (1973). Transplantation Proceedings, 5, 803.

Pegrum, G. D., Evans, Carol A., Middleton, Valerie L., and Balfour, I. C. (1972). Clinical and Experimental Immunology, 10, 67.

Rapaport, F. T., et al. (1971). Transplantation Proceedings, 3, 89.

Steel, C. M., and Hardy, D. A. (1970). Lancet, 1, 1322 